\title{
Det eviga problemet Sverige
}

\author{
Om utgivningen av ny finlandssvensk litteratur $i$ sverigesvenska delupplagor \\ åren 2000-2016
}

FINLANDS IOO-ÅRSJUBILEUM 2017 uppmärksammades relativt stort även i Sverige - med kulturfestivaler, konserter, foto- och konstutställningar, temainslag på bokmässor och andra evenemang. I syfte att kartlägga den sverigesvenska allmänhetens bild av och kunskaper om Finland genomförde opinionsföretaget Novus, på initiativ av Finlandsinstitutet, Kulturfonden för Finland och Sverige samt tankesmedjan Magma, också en större undersökning inför jubileumsåret. Resultaten kan betraktas som nedslående, om än inte förvånande; både den kvantitativa och den kvalitativa delen av undersökningen visar på att sverigesvenskarnas kunskaper om Finland i allmänhet är dåliga. Särskilt utbredd är exempelvis okunskapen om landets språkförhållanden och finlandssvenskarna, något som också bekräftats i tidigare studier. ${ }^{1}$

Artikeln utgör en del av Tomi Riitamaas kommande sammanläggningsavhandling om den nyare finlandssvenska litteraturens position i Sverige. Avhandlingsarbetet har finansierats av Litteraturvetenskapliga nämnden vid Svenska litteratursällskapet i Finland, Svenska kulturfonden i Finland, Sixten Gemzéus stiftelse/Gålöstiftelsen i Sverige, samt genom Riitamaas anställning vid Finsk-ugriska och nordiska avdelningen vid Helsingfors universitet.

I. Undersökningen genomfördes i två delstudier. I den kvalitativa studien framhålls bl.a. följande:"Det råder i samtliga grupper stor osäkerhet när finlandssvenskar kommer på tal. Det är få som har korrekt kunskap och även de som har kunskap känner sig osäkra." Novus. Rapport-Svenskarnas bild av Finland. Del I: Kvalitativ studie, $4 / \mathrm{I}$ 20I7, s. I9, http://www.finlandsinstitutet.se/sv/files/20I7/02/Novus-Rapport-Bildenav-Finland_delı.pdf (hämtad 27/ Io 20I7). Den kvantitativa kartläggningen bekräftar också att det råder"stor osäkerhet i kunskap om finlandssvenskar". Novus. Rapport - Svenskarnas bild av Finland. Del 2: Kvantitativ studie, 7/2 2017, s. 23, http://www. finlandsinstitutet.se/sv/files/20I7/o2/Novus-Rapport-Bilden-av-Finland_del2.pdf (hämtad 27/Io 20I7). I en annan, tidigare undersökning, konstateras också att "finländarna har bättre kunskaper om Sverige än vad svenskarna har om Finland". 
Denna okunskap har länge utgjort ett gissel för finlandssvenskarna, då starka band med och kulturell anknytning till Sverige ofta setts som en ren överlevnadsfråga för finlandssvenskheten per se. ${ }^{2}$ Här spelar litteraturen en viktig roll, något som Hugo Bergroth påtalade redan för över hundra år sedan i sin klassiska Finlandssvenska (1917): "litteraturen är ju [...] ett av de förnämsta medlen att upprätthålla förbindelsen mellan de båda nationaliteterna med svenskt modersmål.”3

Möjligheten att nå ut på en mångdubbelt större arena på det gemensamma språket gör naturligtvis också den sverigesvenska marknaden attraktiv för de finlandssvenska förlagen och för de enskilda författarna. Sammantaget är det därför inte så överraskande att den finlandssvenska litteraturens avsättningsmöjligheter i Sverige har utgjort en knäckfråga i Svenskfinland inte bara under de senaste hundra åren, utan ända från slutet av I80o-talet fram till i dag, vilket Charlotta af Hällström-Reijonen visat. ${ }^{4}$

Hur når då finlandssvenska böcker ut på den sverigesvenska marknaden? I grunden handlar det om huruvida ett sverigesvenskt förlag är villigt att ta in en delupplaga av det finlandssvenska verket för marknadsföring och distribution i Sverige, ofta i utbyte mot att det finlandssvenska förlaget $\mathrm{i}$ sin tur tar in en delupplaga av en sverigesvensk författare. ${ }^{5}$ Systemet med utbyte av delupplagor grundlades

Thorleif Pettersson \& Sakari Nurmela, Om olika sätt att möta en stor elefant. En jämförande studie av finländsk och svensk kultur, Stockholm \& Esbo: Kulturfonden för Sverige och Finland 2007, s. 8. Vidare konstaterar Charlotta Hedberg i en artikel: "Det är vanligt att [sverigesvenskar] har dålig kännedom både om Finland i allmänhet och om den finlandssvenska minoritetsgruppen i synnerhet." Charlotta Hedberg,"Finlandssvenska'ansikten'. Migrationskulturer och livsbanor", Marianne Junila \& Charles Westin (red.), Mellan majoriteter och minoriteter. Om migration, makt och mening, Skrifter utgivna av Svenska litteratursällskapet i Finland (SSLS) 682:2, Helsingfors: SLS 2006, s. I75.

2. Jfr t.ex. Charlotta af Hällström-Reijonen,"Tavaststjerna i provinsialismernas snårskog. Det sverigesvenska förlagsargumentet i finlandssvensk språkvård”, Språk och stil. Tidskrift för svensk språkforskning (ny följd), I7, 2007, s. 154, https://www.kotus. fi/files/912/152-I92.PDF (hämtad 27/ro 2017).

3. Hugo Bergroth, Finlandssvenska. Handledning till undvikande av provinsialismer $i$ tal och skrift, Helsingfors: Holger Schildts förlag I9I7, s. I9.

4. af Hällström-Reijonen, "Tavaststjerna i provinsialismernas snårskog”.

5. En delupplaga utgör alltså en del (storleken varierar) av den totala upplagan som trycks. Vanligtvis görs inga ändringar i bokens inlaga, utan text, formgivning och sättning är desamma i det finlandssvenska förlagets och det sverigesvenska förlagets 
redan i slutet av I80o-talet, då Förlags Ab Söderström \& C:o snart efter bildandet I89I aktivt försökte inleda samarbeten med sverigesvenska förlag. ${ }^{6}$

Söderströms respektive Schildts förlag (grundat I9I3), som under närmare hundra år utgjorde de två stora finlandssvenska förlagen, spelar alltså en central roll i sammanhanget. ${ }^{7}$ År 2012 fusionerades de två förlagen emellertid och bildade nuvarande Schildts \& Söderströms. Tre år senare upplevde den finlandssvenska förlagsbranschen återigen en omvälvning då medierna kunde rapportera att bolaget Moomin Characters Oy Ltd startar ett nytt förlag tillsammans med ett par tongivande redaktörer som sade upp sig från Schildts \& Söderströms. ${ }^{8}$ Med det nya Förlaget ${ }^{9}$ finns nu återigen två större konkurrerande finlandssvenska förlag, en utveckling vars konsekvenser i sammanhanget dock faller utanför tidsramarna för denna studie.

Genom åren har systemet med utbyte av delupplagor, där nationsgränserna styr förlagens respektive verksamhetsområden, ifrågasatts och kritiserats för att vara otympligt och ofördelaktigt. ${ }^{10}$ Flera försök

respektive delar av upplagan. Däremot väljer de sverigesvenska förlagen vanligtvis ett eget omslag, vilket kan se helt annorlunda ut jämfört med det finländska, och trycker även det egna förlagsnamnet och den egna logotypen, inte bara på omslaget utan även på försättsbladet och dylikt. När finlandssvenska förlag tar in delupplagor av sverigesvenska böcker behåller de däremot oftast både ursprungsomslaget och det sverigesvenska förlagsnamnet även på sin del av upplagan som de distribuerar i Finland.

6. Om finlandssvenska förlags försök att etablera sig på den sverigesvenska marknaden genom förlagssamarbeten och uppköp, se avsnittet "Förlagssamarbeten och -uppköp” nedan.

7. Om finlandssvensk bok- och förlagshistoria, se t.ex: Rainer Knapas, "Bokens väg - förlag och distribution", Clas Zilliacus (utg.), Finlands svenska litteraturhistoria. Andra delen: 190o-talet, Helsingfors: SLS / Stockholm: Atlantis 2000, s. 354-36r. Se också historikerna över Söderströms respektive Schildts förlag: Göran Stjernschantz, Ett förlag och dess författare. Söderström E̋ C:0 Förlags AB I89I-I99I, Helsingfors: Söderströms I99r; Henrik Ekberg, Frisinne och kvalitet. Ett sekel med Schildts, Helsingfors: Schildts \& Söderströms 2013.

8. Se t.ex. Linn Karlsson, Stina Sirén \& Maria von Kraemer,"Kända författare väljer det nya Förlaget", Svenska Yle, 7/10 2015 (uppdat. 9/10 2015) https://svenska.yle.fi/ artikel/2015/ro/o7/kanda-forfattare-valjer-det-nya-forlaget (hämtad I2/6 2018).

9. Heter egentligen Förlaget M, men ofta används endast namnformen "Förlaget", så även i denna artikel.

ıо. Se t.ex. Göran Schildt, "Finlandssvenskarna”, Svenska Dagbladet 23/II I959, https:// www.svd.se/finlandssvenskarna (hämtad 30/Io 2017); Peter Curman, "Blir vi nordens [sic] enda land utan nordisk litteratur?", Folket i Bild/Kulturfront, 8-9/1997 
att kringgå detta har också gjorts, framför allt genom de finlandssvenska förlagens etableringsförsök i Sverige. Nya distributionskanaler, som nätbokhandlarna, skapar i dag andra möjligheter för försäljning över nationsgränserna. Det ska också bli intressant att se vilka konsekvenser det faktum att det återigen finns två större förlag i Svenskfinland får för bokproduktionen över lag, i vilken mån de finlandssvenska böckerna når de sverigesvenska läsarna och vilka strategier det nya Förlaget kommer att använda sig av för att ta klivet över den sverigesvenska tröskeln.

Trots kritik och olika alternativa satsningar står systemet med delupplagor fortsatt starkt i dag, och i realiteten utgör en delupplaga på ett sverigesvenskt förlag en grundförutsättning för att ett finlandssvenskt verk ska kunna nå ut ordentligt i Sverige och för att författaren i fråga ska kunna etablera sig på denna marknad. Här ingår synlighet bland annat genom förlagens marknadsföringsapparater, liksom recensioner och intervjuer i dagspress, framträdanden i tv:s morgonsoffor och litteraturprogram samt omnämnande i branschorganens bokkataloger. Naturligtvis finns undantag där författare och verk uppmärksammats stort även utan delupplaga, men de är att betrakta som just undantag. ${ }^{11}$

Diskussionen om den finlandssvenska litteraturens predikament $\mathrm{i}$ Sverige har under senare år präglats av dystra tongångar: man anser att det utkommer för få titlar i delupplagor, att författarna inte uppmärksammas och verken inte recenseras i tillräckligt hög grad, att det finlandssvenska språkbruket skrämmer bort förlag och läsare i Sverige, att sverigesvenskarna är allmänt ointresserade och okunniga, samt att det var bättre förr. ${ }^{12}$ Uppfattningen att läget är prekärt är dock alls

(internetutgåvan), http://old.fib.se/fib_r/finl_sve.html (hämtad 8/6 2018); Petter Olofsson,"Svårt att nå ut i Sverige", Dagens Nyheter 22/6 2003, https://www.dn.se/ arkiv/kultur/svart-att-na-ut-i-sverige/ (hämtad 8/6 2018).

II. Ett exempel är Catharina Gripenberg, som 2016 tilldelades Sveriges Radios lyrikpris och fick mycket uppmärksamhet för diktsamlingen Handbok att bära till en dräkt, Helsingfors: Schildts \& Söderströms 20I6, trots att den inte utkommit i sverigesvensk delupplaga. "Gripenberg får SR:s lyrikpris", Hufoudstadsbladet 22/II 2016, https:/www.hbl.fi/artikel/gripenberg-far-srs-lyrikpris/ (hämtad 7/6 2018).

I2. Se t.ex. Ludvig Hertzberg,"Samma gamla dilemma", $N y$ Tid I5/2 2010, http://www. nytid.fi/2oro/o2/samma-gamla-dilemm/ (hämtad 30/Io 20I7); Merete Mazzarella, "Finlandssvensk litteratur i tidningskrisen", Dixikon I3/II 20I2, https://www.dixikon.se/finlandssvensk-litteratur-i-tidningskrisen/ (hämtad 30/Io 20I7); Andrea Svanbäck, "Den höga rikssvenska tröskeln", Hufvudstadsbladet I/IO 20I2, http:// 
inte ny; de dystra tongångarna har ljudit högt allt sedan I8oo-talet. ${ }^{13}$ Men hur ser situationen egentligen ut i dagens läge? Är det verkligen så illa? Hur många - eller få - finlandssvenska verk utkommer i delupplagor på sverigesvenska förlag? Trots det stora intresse som ägnats problematiken i över ett sekels tid, lyser vetenskapliga studier som $\mathrm{i}$ ett bredare perspektiv tar fasta på sådana frågor nästan helt med sin frånvaro. ${ }^{14}$

gamla.hbl.fi/kultur/20I2-ıo-oI/den-hoga-rikssvenska-troskeln (hämtad 30/ıo 20I7); Philip Teir, "Ny vår för finlandssvenskarna", Vi Läser, 20I2:5, http://vilaser. se/finlandssvenskans-sak-ar-svar/ (hämtad 30/ıo 20I7); Ebba Witt-Brattström, "Finlandssvenskarna ligger steget före", Dagens Nyheter II/I2 20I3; Madeleine Grive, "På östfronten allt nytt", ooTAL, 2009: 29, http://www.Iotal.se/?p=I72I (hämtad 7/4 2017); Linnea Hanell (med kommentar av Catharina Grünbaum), Det går hårt åt. Finlandssvenska ur ett sverigesvenskt perspektiv, Magma-studie 4/20Ir, Helsingfors: Finlands svenska tankesmedja Magma 2oII, http://magma.fi/uploads/media/stu dy/ooor/or/oe928f4292c975d882cab642d3a5ef $4 f_{53}$ O4dd9r.pdf (hämtad 8/6 2018).

13. Redan så tidigt som år 1826 diskuterades mottagandet i Sverige av litteratur skriven på svenska i Finland i svallande och förnärmade ordalag; se Otto Tulindberg, Terpsichore. Wittra och Wettenskapliga Försök, Andra häftet, Helsingfors: tryckt hos J. Simelii Enka I826, s. IV-XXVII. Se också Ekberg, Frisinne och kvalitet, s. 366, som ägnar ämnet ett längre avsnitt under rubriken "Problemet Sverige ett evighetsproblem", och konstaterar:"Alltsedan sent I80o-tal har man i Finland - med rätt eller orätt - hyst uppfattningen att den finlandssvenska litteraturen blir styvmoderligt behandlad i Sverige." Se även t.ex. Bergroth, Finlandssvenska; Schildt, "Finlandssvenskarna".

I4. I två tidigare artiklar tangerar jag dessa frågor. Se Tomi Riitamaa, ”... och något omisskännligt mumindalskt .... Det sverigesvenska förlagsargumentet, UllaLena Lundbergs Marsipansoldaten och recensenternas syn på romanens språk”, Kirjallisuudentutkimuksen aikakausilebti Avain 2015:2, s. 49-63; Tomi Riitamaa, "Den 'förvånansvärt obildade kråkan'. Om Lars Sunds roman Tre systrar och en berättare och läsaren", Samlaren. Tidskrift för forskning om svensk och annan nordisk litteratur 2015:136, s. 203-230, http://uu.diva-portal.org/smash/get/ diva2:911003/FULLTEXTor.pdf (hämtad 25/6 2018). Tematiken berörs också delvis av af Hällström-Reijonen, "Tavaststjerna i provinsialismernas snårskog", samt Ellen Bijvoet \& Liesbet Vannyvel, "Två länder, två språk? Om förlagspolitik i fråga om pluricentrisk språkvariation”, Anja Saxena (red.), Språkets gränser och gränslöshet. Då tankar, tal och traditioner möts, Uppsala: Uppsala universitet 20or, s. 8I-89. Jag har även funnit två examensarbeten som kretsar kring dessa spörsmål ur olika perspektiv: Majvor Bengtsson \& Lena Eng, Tjugo moderna svenskspråkiga författare i Finland: med belysning av den finlandssvenska litteraturbistorien, forfattarnas historiska, geografiska och sociala miljö samt den finlandssvenska bokens väg till de rikssvenska läsarna, otryckt specialarbete inom ämnet litteraturorientering och bibliografi vid Bibliotekshögskolan i Borås, Vt I976, http://hdl.handle. net/2320/9163 (hämtad 30/10 20I7), samt Kurt Levlin, Den undanskymda litteraturen. En undersökning av den finlandssvenska skönlitteraturens ställning i Sverige, 
Syftet med föreliggande artikel är att generera ny kunskap om den finlandssvenska litteraturens position i Sverige, genom att undersöka utgivningen av ny finlandssvensk skönlitteratur i sverigesvenska delupplagor åren 2000-20I6 systematiskt och kvantitativt. Resultaten tyder, som vi ska se, på att den pessimistiska hållningen inte helt stämmer överens med hur det förhåller sig i verkligheten.

\section{UTGÅNGSPUNKTER FÖR STUDIEN}

I introduktionen till antologin Svensk litteratur som världslitteratur (20I2) diskuterar litteratursociologen Johan Svedjedal metodologiska aspekter och problem i anslutning till studiet av den sverigesvenska litteraturens position på världsmarknaden, och menar bland annat att den "metodiskt bästa vägen för att få en översiktlig bild av svensk skönlitteraturs plats i världen är [...] att först försöka få en uppfattning om utflödesnivån [...]", för att först därefter "gå vidare till mer detaljerade studier av enskilda författarskap". På detta sätt, påpekar Svedjedal vidare, blir det möjligt att "låta djupstudierna få relief av den bredare kontext som en systematisk bearbetning utgör". ${ }^{15}$

I syfte att frammana en bredare bild av den finlandssvenska litteraturens spridning i Sverige av i dag, tar jag här fasta på Svedjedals metodologiska förslag, om än i modifierad form. I en kvantitativ ansats studerar jag utflödet av finlandssvensk skönlitteratur till Sverige genom att undersöka utgivningen av delupplagor hos sverigesvenska förlag under en avgränsad period. Eftersom syftet är att ge en så dagsaktuell bild som möjligt av situationen, har jag valt att fokusera utgivningen under åren 2000-2016. För att få ett brett historiskt, jämförande perspektiv vore det naturligtvis önskvärt att utvidga undersökningen tidsmässigt och ta fasta på hela den halvtannat sekel långa period då problemet stått $\mathrm{i}$ centrum $\mathrm{i}$ samtalet om den finlandssvenska litteraturen. Eftersom det saknas statistiska uppgifter över utgivningen

otryckt magisteruppsats, Avdelningen för biblioteks- och informationsvetenskap, Sociologiska institutionen, Umeå universitet 2003.

I5. Johan Svedjedal, "Svensk skönlitteratur i världen. Litteratursociologiska problem och perspektiv", Johan Svedjedal (red.), Svensk litteratur som världslitteratur. En antologi, Uppsala: Avdelningen för litteratursociologi, Uppsala universitet 20I2, s. 64 . 
av delupplagor, och då det är oerhört tidskrävande att inhämta och sammanställa sådana uppgifter, kräver ett dylikt projekt en betydligt större insats än den som är möjlig att genomföra här. Ett jämförande perspektiv med tidigare utgivning är emellertid möjligt att anlägga, då en uppsats av Majvor Bengtsson och Lena Eng presenterar vissa uppgifter om utgivningen i delupplagor under 1960- och I970-talen. ${ }^{16}$

Därtill har jag valt att fokusera förstaupplagor av skönlitterära verk för vuxna av författare som varit aktiva under hela eller delar av 2000-talet. Utanför studiens ramar faller således tidigare verksamma författare vars verk fortfarande utkommer i nyutgåvor och nya upplagor, som Johan Ludvig Runeberg, Zacharias Topelius, Edith Södergran, Tove Jansson och Solveig von Schoultz för att nämna några av de mest uppenbara och i Sverige genom tiderna mest spridda. Likaså faller barn- och ungdomslitteratur, facklitteratur och annan sakprosa utanför denna studie.

Genreavgränsningar är ofta vanskliga, och en fråga som uppstått i arbetet gäller essäistiken. Jag har valt att utesluta denna litteraturform, trots att en hel del essäistik kan betraktas som skönlitteratur. Anledningen till detta är svårigheten i att dra en gräns mellan skönlitterär essäistik och facklitterär, vetenskaplig eller annan essäistik som kan betraktas som sakprosa. I en systematisk undersökning förefaller det mera ändamålsenligt att utesluta all essäistik, i stället för att ta med vissa verk och utesluta andra. Det här innebär att några framstående och i Sverige spridda författarskap av i dag faller utanför - som exempelvis största delen av Merete Mazzarellas litterära produktion. Likaså är gränsen mellan skönlitteratur och biografier samt memoarer ibland svår att dra. I tveksamma fall - och det här gäller samtliga genredefinitioner i studien - har jag genomgående utgått från de utgivande förlagens definition. Detta medför exempelvis att ett verk som Jörn Donners Mammuten (2012) inte inkluderas, trots att författaren själv har hävdat att verket bör läsas som fiktion, som en roman. Likt Mazzarella är Donner (som över tid och sett till totalt antal delupplagor, ett sextiotal, möjligen är den i Sverige mest spridda finlandssvenska författaren) här representerad av endast ett verk.

16. Se Bengtsson \& Eng, Tjugo moderna svenskspråkiga författare i Finland, s. 9. 
Då jag är intresserad av att specifikt titta närmare på utflödet av finlandssvensk litteratur till Sverige, inkluderas inte heller sådana skönlitterära författarskap som i första hand eller enbart utges i Sverige. Exempelvis Ålandsbördiga men sedan länge i Sverige bosatta Liselott Willén, med ett antal romaner utgivna på sverigesvenska förlag, beaktas alltså inte. Däremot inkluderas Lars Sund, född och uppvuxen i Österbotten men även han sedan länge bosatt i Sverige, eftersom hans verk i första hand utkommer på Schildts \& Söderströms och i andra hand som delupplagor i Sverige.

I fokus står alltså fiktionslitteraturen för vuxna: romaner, novellsamlingar och diktsamlingar i originalutgåva, utgivna under 2000-talet i Finland och delutgivna av sverigesvenska förlag. Dessa avgränsningar innebär att studien inte aspirerar på att ge en helhetsbild av spridningen av finlandssvensk litteratur i Sverige. Mitt syfte är i stället att alstra kunskap om vilket slags ny skönlitteratur som intresserar de sverigesvenska förlagen och som därmed når det litterära fältet $\mathrm{i}$ Sverige, bokhandlarna, biblioteken, tidningsrecensenterna och läsarna, och i vilken omfattning.

Följande frågor ställer jag till mitt material:

Hur många verk som motsvarar de ovan beskrivna kriterierna har utgivits som delupplagor under perioden 2000-2016, och hur många har utgivits per år under denna period?

Hur står sig utgivningstakten mot den under 1960- och 1970-talen?

Hur stor andel av Schildts, Söderströms och senare Schildts \& Söderströms verk har getts ut i delupplagor i Sverige under perioden?

Vilka författare ges ut i delupplagor under perioden? Hur ser könsoch åldersfördelningen ut bland dessa?

Hur ser den genremässiga fördelningen (romaner, novellsamlingar och diktsamlingar) ut i utgivningen av delupplagor under perioden?

Vilka sverigesvenska förlag har utgivit delupplagor under perioden? 
I arbetet med att ta fram uppgifter om delupplagor har jag inledningsvis konsulterat databasen Libris (libris.kb.se) som nu för tiden fungerar som Sveriges nationalbibliografi. Där har jag använt mig av SAB-koden för finlandssvensk skönlitteratur, Hcd. ${ }^{17}$ Jag har sedan avgränsat träffmängden tidsmässigt och materialmässigt (genom att sortera bort ljudupptagningar, elektroniskt material och liknande) och gått igenom träfflistan för perioden 2000-2016 år för år. Ett skönlitterärt verk i tryckt förstaupplaga av en finlandssvensk författare som utgivits i delupplaga i Sverige får då i idealfallet två träffar, där den ena anger det finländska förlagets upplaga och den andra träffen det sverigesvenska förlagets delupplaga. Johan Svedjedal menar att det finns stora brister i hur materialet har katalogiserats i Suecana extranea ${ }^{18}$, och denna omständighet är tyvärr påtaglig även för det registrerade materialet under $\mathrm{SAB}$-koden Hcd, oavsett om upplagan är utgiven i Finland eller i Sverige. Ett av många exempel är UllaLena Lundbergs roman $I s$ (20I2), som inte får någon träff om man söker på tryckt material under SAB-koden Hcd. Däremot återfinns verket som talbok. Gör man en manuell sökning i Libris på sökorden "Ulla-Lena Lundberg Is" får man däremot träff på både Schildts \& Söderströms upplaga och Bonniers delupplaga.

En sådan sökning kräver förstås att man vet vad man skall söka efter. Jag har därför gått igenom utgivningen hos Schildts och Söderströms respektive Schildts \& Söderströms år för år i Den finlandssvenska bokkatalogen,${ }^{19}$ för att därefter i Libris manuellt söka på sådana aktuella verk och författare som inte återfinns under SAB-koden Hcd. Jag har även konsulterat sverigesvenska förlags utgivningskataloger och webbsidor vid misstanke om bristfällig katalogisering i Libris. I ett par oklara fall har jag haft kontakt via e-post med förlag och frågat om deras utgivning av ett aktuellt verk.

I7. SAB är det allmänna klassifikationssystemet för bibliotek i Sverige. SAB-koden Hcd står för "finlandssvensk skönlitteratur".

I8. Suecana extranea är en bibliografi/deldatabas i Libris där utländsk litteratur med svensk anknytning förtecknas.

19. Den finlandssvenska bokkatalogen listar årligen böcker och tidskrifter som utkommit på finlandssvenska förlag. Katalogen utges av Svenska kulturfonden och Föreningen Konstsamfundet. 
Utifrån de insamlade uppgifterna har jag sammanställt en bibliografi över periodens utgivna verk utifrån urvalskriterierna och avgränsningarna. Bibliografin, som medföljer som bilaga i slutet av artikeln, presenterar följande uppgifter: författarnamn, verktitel, utgivningsår, genre, förlag i Sverige. Uppgifterna i bibliografin utgör i sin tur grund för de statistiska uppgifter och de svar på ovanställda frågor som jag presenterar i denna artikel.

Ytterligare ett par omständigheter beträffande materialet bör beröras här. Märta Tikkanen menar, i en intervju med Andrea Svanbäck i Hufvudstadsbladet år 2012, att grundförutsättningen för att en finlandssvensk författare ska kunna hoppas på en sverigesvensk delupplaga är att hen blir utgiven hos Schildts \& Söderströms:"Schildts \& Söderströms utgör fortfarande nålsögat, det hänger i hög grad på deras kontakter hur väl böckerna kommer vidare. ${ }^{20}$ Under arbetet med insamlandet av data om utgivningen har jag blivit varse hur rätt Tikkanen har: det stod nämligen snart klart att samtliga av de nya skönlitterära verk med sverigesvensk delupplaga som jag funnit uppgift om fram till och med slutet av 2016 utgivits i Finland av antingen Schildts, Söderströms eller det sedan 2012 fusionerade Schildts \& Söderströms. I dag är situationen en annan på så sätt att det nya Förlaget är att betrakta som en fullödig konkurrent till Schildts \& Söderströms, och under 2017 och 2018 har också delupplagor av förlagets utgivning utkommit i Sverige.

Nämnda inkonsekvenser i katalogiseringen av finlandssvensk skönlitteratur under dess rätta SAB-kod Hcd i Libris, samt möjligheten att förlag inte alltid skickat in pliktexemplar till Kungliga biblioteket (och att verket i fråga därför inte kunnat registreras i Libris), innebär att det möjligen saknas verk $\mathrm{i}$ bibliografin som enligt kriterierna borde ha varit med - framför allt sådana som är utgivna av mindre förlag i Finland och i Sverige och som jag inte funnit uppgifter om. Bibliografin är alltså inte nödvändigtvis fullständigt heltäckande. Den torde ändå ge en nästintill komplett bild av den nyare finlandssvenska skönlitteraturens spridning genom delupplagor i Sverige åren 2000-20I6.

20. Svanbäck, "Den höga rikssvenska tröskeln". 


\section{DET VAR INTE B ÄTTRE FÖRR}

Enligt de uppgifter jag har tagit fram utgavs åren 2000-20I6 sammanlagt 67 skönlitterära verk som tveklöst motsvarar urvalskriterierna i sverigesvensk delupplaga. Som framgår av Diagram I var utgivningen av delupplagor som störst 2013, då det utgavs sju titlar under ett och samma år. Noterbart är att det under år 2016 inte utgavs ett enda nytt verk i delupplaga. Det går ändå inte att utläsa något enhetligt mönster eller någon riktgivande trend i utgivningen; det finns genom hela den undersökta perioden en pendling vad gäller antalet utgivna finlandssvenska verk i delupplagor. Också avbrottet i utgivningen av delupplagor år 2016 verkar vara tillfälligt. Under år 20I7 utkom åtminstone Philip Teirs, Kjell Westös och Johanna Holmströms nya romaner samt debutanten Martina Moliis-Mellbergs diktsamling i delupplagor. Under våren 2018 har åtminstone Jörn Donners nya roman samt EvaStina Byggmästars nya diktsamling utkommit, och till hösten detta år planeras åtminstone Tua Forsströms nya diktsamling utkomma. Fluktuationen i utgivningen kan förklaras av de i Sverige regelbundet utkommande finlandssvenska författarnas utgivningscykler. Råkar det sig så att ingen av dem ger ut en ny bok under det aktuella året, så utkommer naturligtvis heller ingen delupplaga i Sverige.

Det sammanlagda antalet verk ger ett genomsnitt på knappt fyra titlar per år under perioden. Under samma period utgav Schildts och

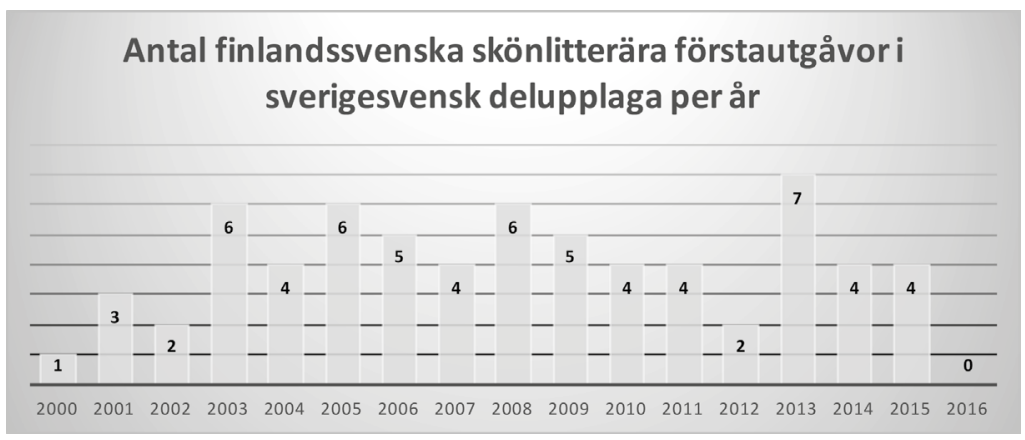

Diagram $I$. 
Söderströms, respektive Schildts \& Söderströms, totalt 353 skönlitterära verk av finlandssvenska författare som motsvarar kriterierna i studien, vilket ger en utgivningstakt på knappt 2 I verk per år. ${ }^{21}$ Detta innebär att andelen verk som under perioden utkommit även i sverigesvensk delupplaga utgör en knapp femtedel, cirka I9 procent av det totala antalet verk. ${ }^{22}$

Eftersom det i stort sett saknas statistik och studier över den tidigare utgivningstakten av delupplagor är det svårt att göra jämförelser bakåt i tiden. Ett undantag är Majvor Bengtssons och Lena Engs uppsats Tjugo moderna svenskspråkiga författare i Finland (1976), som belyser spridningen av den finlandssvenska litteraturen i Sverige under 1960- och 1970-talen. Här presenteras visserligen ingen årlig statistik, men uppsatsförfattarna anger genomsnittliga uppgifter för hela perioden, både gällande den totala utgivningen hos Schildts och Söderströms förlag, samt för andelen av dessa verk som översätts till finska respektive ges ut i delupplagor av förlag i Sverige. Enligt Bengtsson och Eng utgav Schildts och Söderströms i snitt sammanlagt ett trettiotal nya skönlitterära titlar årligen under 1960- och 1970-talen. Av dessa förmedlades två till sex titlar (en till tre titlar från respektive förlag) per år som delupplagor till förlag i Sverige. ${ }^{23}$ Bortser man från bottennoteringarna år 2000 (en titel) och år 2016 (inga titlar), samt toppnoteringen år 2013 (sju titlar), ser man i Diagram I att siffrorna gällande 2000-talet likaså varierar mellan två och sex titlar per år. Utgivningstakten av delupplagor ligger alltså på samma nivå under perioden 2000-2016 som på I960- och I970-talen. Beaktar man att utgivningen hos Schildts och Söderströms förlag samtidigt tycks ha minskat - från ett trettiotal titlar per år till ett tjugotal blir det också tydligt att den andel av utgivningen som utkommer i delupplagor i Sverige snarare har vuxit om man jämför perioderna. Bengtsson och Eng talar visserligen om att"ungefär en femtedel [...] av de finlandssvenska böckerna sprids i Sverige" (att jämföra med en knapp femtedel under 200o-talet), men denna beräkning tycks ba-

2I. Uppgifterna har inhämtats i Den finlandssvenska bokkatalogen.

22. Andelen gäller alltså verk utgivna av Schildts, Söderströms och senare av Schildts \& Söderströms. Räknar man med verk från samtliga finlandssvenska förlag, blir andelen titlar i sverigesvensk delupplaga naturligtvis mycket mindre.

23. Bengtsson \& Eng, Tjugo moderna svenskspråkiga författare i Finland, s. 9 f. 
seras på toppnoteringar under enskilda år, då sex av cirka trettio verk utkom i Sverige. I vilket fall som helst går det att konstatera, utifrån dessa uppgifter, att sverigesvenska delupplagor av ny finlandssvensk skönlitteratur inte har minskat i antal under 200o-talet jämfört med I960- och r970-talen - tvärtemot den gängse uppfattningen.

\section{DEN FÖRFÖRDELADE LYRIKEN?}

Lyriken betraktades länge som den finlandssvenska litteraturens paradgren, medan romankonsten inte ansågs hålla tillräckligt hög klass, utan många gånger beskylldes för att vara borgerligt inskränkt samt nationellt och regionalt sett navelskådande. ${ }^{24}$ Sedan r99o-talets finlandssvenska romanboom har förhållandet förändrats. Monika Fagerholm, Kjell Westö, Ulla-Lena Lundberg, Lars Sund, Johanna Holmström, Philip Teir och andra har de senaste decennierna skrivit ett flertal uppmärksammade och hyllade romaner, och förskjutningen i uppmärksamhet har på sina håll lett till uppfattningen att lyriken på senare tid blivit styvmoderligt behandlad och förbisedd. Ett uttryck för detta är utgivningen av Poesin. En debattbok (2014), en korrespondens mellan sex finlandssvenska poeter om den finlandssvenska lyrikens situation. Utgivningen i Sverige har ingen framträdande roll i samtalet, men Ralf Andtbacka framhåller vid ett par tillfällen att läget också på den fronten ser mörkt ut: "Situationen västeröver är inte bättre. Ännu på 9o-talet var det självklart att de mest kända finlandssvenska poeterna gavs ut i Sverige. Det är det inte längre." ${ }^{25}$ Senare i boken skriver Andtbacka: "Och trots alla kontakter är det få finlandssvenska poeter som kommer ut i Sverige [...]." ${ }^{26}$ Också Henrika Ringbom ser dystert på nuläget i det här avseendet, även om hon hoppas på framtiden:

24. Se t.ex. Thomas Warburton, Attio år finlandssvensk litteratur, Helsingfors: Holger Schildts förlag 1984, framför allt s. II-I6.

25. Ralf Andtbacka,"Ralf, brev 3", Matilda Södergran, Henrika Ringbom, Peter Mickwitz, Agneta Enckell, Tatjana Brandt \& Ralf Andtbacka, Poesin. En debattbok, Vasa: Ellips förlag 2014, s. 69.

26. Ralf Andtbacka,"Ralf, brev 4", Matilda Södergran, Henrika Ringbom, Peter Mickwitz, Agneta Enckell, Tatjana Brandt \& Ralf Andtbacka, Poesin. En debattbok, Vasa: Ellips förlag 20I4, s. Iıo. 
Mitt hopp står långt till att nationsgränsernas betydelse kommer att minska, och att den poesi som skrivs här i öst i allt högre grad ska börja ses som en självklar del av den svenska och övriga skandinaviska lyriken. Å andra sidan, redan nu plockar man i Sverige åt sig russin som Edith Södergran, medan större delen av den poesi som idag skrivs här inte syns i svensk litterär offentlighet. ${ }^{27}$

Också i sverigesvensk press har specifikt den finlandssvenska lyrikens situation i Sverige diskuterats några gånger under 2000-talet. Tonläget har då om möjligt varit ännu dystrare än när den finlandssvenska litteraturen i stort behandlats. I en understreckare i Svenska Dagbladet skriver Tom Hedlund, under den braskande rubriken "Finlandssvensk lyrik är förföljd av nonchalans", att den finlandssvenska och den sverigesvenska lyriken började utvecklas isolerade från varandra efter modernismen då tongivande finlandssvenska modernister gav livgivande impulser västerut:

Därmed försvann finlandssvenskarna också i stort sett ur det rikssvenska synfältet. Enstaka poeter efter 2o-talsgenerationen, framför allt Solveig von Schoultz och Bo Carpelan, liksom senare Märta Tikkanen, har i någon mån uppmärksammats också i Sverige. ${ }^{28}$

Under rubriken "Kunskapsluckan: Finlandssvensk lyrik" skriver Ann Lingebrandt i Helsingborgs Dagblad för sin del:

Över Östersjön hörs de poetiska nödropen ytterst svagt: i Sverige är intresset för det finlandssvenska obetydligt och många tror att mumintrollen egentligen talar finska. Det är ett såväl bokstavligt som bildligt hav mellan de forna broderfolken. ${ }^{29}$

27. Henrika Ringbom,"Henrika, brev 5", Matilda Södergran, Henrika Ringbom, Peter Mickwitz, Agneta Enckell, Tatjana Brandt \& Ralf Andtbacka, Poesin. En debattbok, Vasa: Ellips förlag 20I4, s. I28.

28. Tom Hedlund, "Finlandssvensk lyrik är förföljd av nonchalans”, Svenska Dagbla$\operatorname{det}$ I2/I2 200I, https://www.svd.se/finlandssvensk-lyrik-ar-forfoljd-av-nonchalans (hämtad I8/4 20I7).

29. Ann Lingebrandt, "Kunskapsluckan: Finlandssvensk lyrik", Helsingborgs Dagblad 9/I2 20I4, http://www.hd.se/20I4-I2-o9/kunskapsluckan-finlandssvensk-lyrik (hämtad I8/4 20I7). 


\section{Sverigesvenska delupplagor av finlandssvenska skönlitterära förstautgåvor åren 2000-2016, genremässig fördelning}

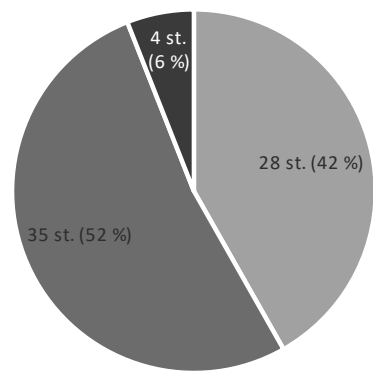

Romaner Lyrik Noveller

Diagram 2.

Men är det då verkligen så illa ställt med den finlandssvenska poesins status i Sverige? Min undersökning ger en mera positiv bild av situationen, då man jämför andelen lyrik med andelen prosa i sverigesvenska delupplagor åren 2000-2016. Som framgår i Diagram 2 utgör diktsamlingar faktiskt över hälften ( 52 procent) av de 67 titlar som utkommit i delupplagor. Nämnas bör också att jag uteslutit ytterligare tre diktverk, som utgjorde gränsfall i förhållande till urvalskriterierna. Förlaget Modernista tog 2007 in en mindre delupplaga (50-100 ex.) från Söderströms av Philip Teirs diktsamling Någonting ur hennes mun faller $i$ min mun, för distribution i Sverige. ${ }^{30}$ Då man inte gett ut den under eget förlagsnamn, utan enbart distribuerat titeln under det finlandssvenska förlagsnamnet, har jag emellertid inte tagit med denna bok i statistiken. Samma sak gäller Ralf Andtbackas diktsamling Wunderkammer, där Pequod Press distribuerade en mycket liten upplaga i Sverige. ${ }^{31}$ Det av Jörn Donner initierade flerbandsverket

30. Information per e-post 22/3 2017 från Modernista.

31. Anders Bräck vid Pequod Press skriver i e-post 21/320I7 om Andtbackas diktsamling: "när det gäller 'Wunderkammer' kan man nog inte kalla det annat än att vi hjälpte till med distributionen i Sverige. Vi tog hand om ett tiotal ex som las in i vår katalog hos Förlagssystem, vilket gjorde det lättare för bokhandlarna i Sverige att ta in den. Vi hade även med den på vår hemsida, sålde den på bokmässan $\mathrm{i}$ Göteborg etc. Vi hade inte [något] som helst inflytande över utgivningen i övrigt." 


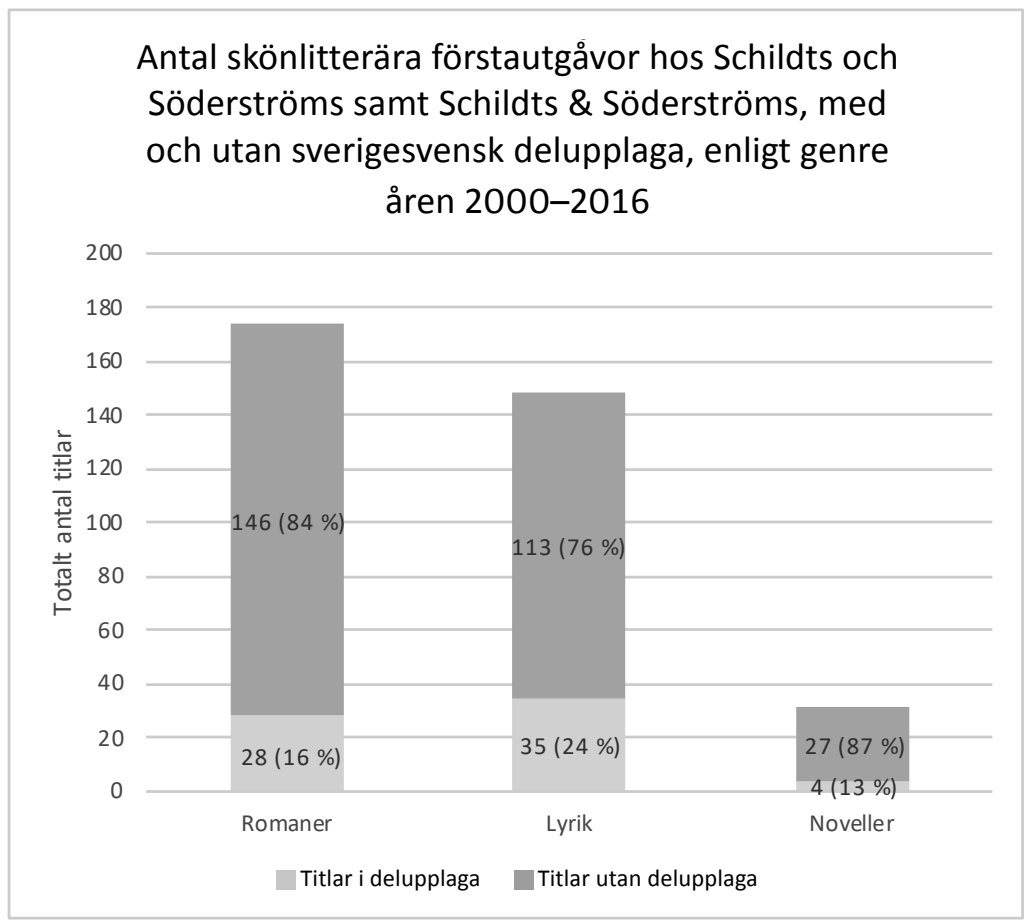

Diagram 3 .

Den finlandssvenska dikten, i Bonniers delupplaga 200I, består av I6 band, där vart och ett innehåller ett urval av en enskild finlandssvensk diktares produktion. Då flera av författarna inte längre varit verksamma under undersökningsperioden, faller även detta verk utanför kriterierna.

Ser man till andelen delupplagor av den sammanlagda utgivningen hos Schildts, Söderströms och Schildts \& Söderströms under perioden, blir det än tydligare att den finlandssvenska lyrikens ställning beträffande utgivningen i delupplagor i Sverige är god i relation till prosans. Under perioden dominerade nämligen prosan i den finlandssvenska utgivningen, vilket innebär att andelen lyrikverk som också utgavs i Sverige överstiger andelen prosaverk. Som framgår av Diagram 3 utgavs nästan vart fjärde lyrikverk (24 procent) i delupplaga, medan knappt var sjätte roman (I6 procent), respektive var åttonde novellsamling ( 13 procent), gavs ut i delupplaga. 
Beträffande genrefördelningen i utgivningen av delupplagor under 1960- och 1970-talen framhåller Bengtsson och Eng att "så gott som alla är prosaböcker". ${ }^{32}$ De anför emellertid inga siffror, och det kan vara klokt att förhålla sig litet avvaktande till en så pass resolut formulering. En sökning i Libris på ett par av periodens verksamma finlandssvenska diktare ger vid handen att enbart Claes Andersson (sex) och Bo Carpelan (fem) sammanlagt utkom med elva diktsamlingar i delupplagor under 1960- och 1970-talen.

Det står emellertid klart att prosan utgjorde den stora majoriteten av periodens delupplagor. Jämfört med perioden 2000-2016, där alltså över hälften av delupplagorna utgörs av diktsamlingar, ser vi att det utkommer fler diktsamlingar i dag än för ett halvsekel sedan - de dystra utsagorna till trots.

\section{FÖRLAGSSAMARBETEN OCH -UPPKÖP}

Om man uppmärksamt läser en följd av svenska kritiker öfver finska [finlandssvenska] arbeten, skall man finna att de i stort sedt mynna ut i beröm öfver den friskhet och känslighet som hvilar över dem. Det är sentiment utan sentimentalitet som hos våra finska skriftställare tjusar den svenska läsaren. I själfva verket, medan det genom diktningen går ett - i ordets vackraste bemärkelse - aristokratiskt drag, klingar vår sång enklare, den värkar med små medel, dess behag är en varm, en folkelig ton, som rör och vinner hjärtan. Utan att tala i hög ton kan man väl säga, att mycket af välklangen i den svenska sången och nutida diktningen vore borta ifall den svensk-finska en dag skulle förklinga och tystna. [...] Så länge svenska skrifves i Finland, så länge den svensk-finska diktningen fritt och obehindrat låter sig höra i vårt land, så länge svenska böcker gifvas ut i Finland, skall den svenska bokmarknaden här finna ett för densamma, vi våga tro, högst betydande fält. ${ }^{33}$

De högstämda raderna är ett utdrag ur en broschyr med titeln "Till Svenska allmänheten” som Söderströms förlag distribuerade i Sverige i

32. Bengtsson \& Eng, Tjugo moderna finlandssvenska författare, s. Io.

33. Fridolf Vladimir Gustafsson, "Till Svenska allmänheten", I894 (broschyr som Söderströms förlag distribuerade i Sverige). Citerat från Stjernschantz, Ett förlag och dess forfattare, s. 3I $\mathrm{f}$. 
februari 1894. Broschyren var en del av Söderström \& Co:s satsningar endast ett par år efter att förlaget grundats år I89I, då man aktivt försökte ingå samarbete med sverigesvenska förlag genom utbyte av delupplagor. Framför allt Albert Bonnier visade initialt intresse, och åren kring sekelskiftet var kontakterna givande. ${ }^{34}$ Snart svalnade emellertid intresset i Sverige då försäljningen av de finlandssvenska verken gick trögt. Framstötarna från Söderströms och Schildts förlag, och försöken att på olika sätt etablera sig på den sverigesvenska marknaden, fortsatte dock envetet under hela i9oo-talet. ${ }^{35}$ Intresset från förlagen på andra sidan havet varierade dock under seklet. Henrik Ekberg skriver i sin historik över Schildts förlag:

Finlands sak är vår-andan som uppstod under vinterkriget gjorde otvivelaktigt de svenska förlagen åtminstone temporärt mottagligare för samarbetsinviter från finlandssvenskt håll, men efterhand blev umgänget allt affärsmässigare och nya svenska förläggargenerationer för vilka beviljandet av favörer till stamfränderna östanhavs var främmande trädde till. ${ }^{36}$

Ytterligare ett uppsving skedde mot slutet av I970-talet, då Daniel Hjort tillträdde som chef för det Bonnierägda och nybildade förlaget Alba. Under Hjort hade Alba en egen nisch för finlandssvensk litteratur, och fram till I992, då Hjort gick i pension och förlaget ombildades till Bonnier Alba, utkom många finlandssvenska författares verk i delupplagor hos förlaget. ${ }^{37}$

Efter millennieskiftet har de finlandssvenska förlagen oförtrutet fortsatt att försöka förbättra sina positioner på den sverigesvenska marknaden för att lättare kunna sprida den finlandssvenska litteraturen där. Det har skett inte minst genom uppköp av ägarandelar i sverigesvenska förlag. I början av 200 r rapporterade medierna att

34. Stjernschantz, Ett förlag och dess författare, s. 32.

35. Om framstötar och etableringsförsök i Sverige, förlagssamarbeten och liknande, se historikerna över förlagen: Stjernschantz, Ett förlag och dess författare, framför allt s. I9, 3i f., 35 f., 6r f., 73, 92-97, п13-II8, г59-I62, г88-г97, 226, 236-239, 295 f., respektive Ekberg, Frisinne Eं kvalitet, framför allt s. I5, 69 f., 87 f., 93-95, II2-II9, I37, 236, 366-372.

36. Ekberg, Frisinne E kvalitet, s. 368.

37. Ibid. 
bokförlaget Atlantis i Sverige fått finlandssvensk ägarmajoritet, med Svenska litteratursällskapet i Finland (SLS) som största ägare, och med Söderströms, Föreningen Konstsamfundet och Niilo Helanders stiftelse som andra finländska delägare. ${ }^{38}$ Samma år tog Schildts de första stegen mot att förvärva ägande i bokförlaget Alfabeta, då man var rädd att författarna skulle fly till konkurrenten som hade fått bättre tillgång till den svenska marknaden. År 2003 slutfördes affären, och tanken var inledningsvis att en tredjedel av Schildts verk skulle utkomma i delupplaga hos Alfabeta, och att andelen sedan skulle öka successivt. ${ }^{39}$

Problem uppstod emellertid snabbt. Enligt ett tidigare avtal innehade Rabén \& Sjögren distributionsrätten till Tove Janssons Muminböcker i Sverige. Då Schildts ansåg att förlaget brutit mot avtalet genom att distribuera Muminböcker också i Finland överlät man distributionsrättigheterna på den sverigesvenska marknaden till Alfabeta. Detta medförde att Norstedts förlagsgrupp, som ägde Rabén \& Sjögren, inledde en rättsprocess mot Schildts. Rätten dömde emellertid till Schildts fördel på alla punkter, men tvisten skadade sedermera relationen med Norstedts. ${ }^{40}$ Dessutom fungerade inte samarbetet med Alfabeta som det var tänkt. Enligt Schildts visade sig förläggaren bara "benägen att plocka russinen ur kakan" av förlagets finlandssvenska titlar, och hela affären - vilken beskrivs som "ett enda stort misslyckande" - blev ytterst förlustbringande för Schildts. ${ }^{41}$ Efter långvariga schismer sålde Schildts, som ägt 40 procent av aktierna i Alfabeta, år 2008 tillbaka 35 procent till Alfabetas förläggare. ${ }^{42}$

Också Atlantis-affären slutade sedermera olyckligt för de finlandssvenska ägarna. Svenska Akademiens dåvarande ständiga sekreterare Peter Englund lämnade år 2013 förlaget med medialt buller och bång, efter osämja med ägarna om kommande reformer. Samtidigt kom rapporter om att flera andra av förlagets tongivande författare pla-

38. Yvonne Lindberg, "Atlantis blir halvfinskt", Svensk Bokhandel 9/2 200I, http:// www.svb.se/nyheter/atlantis-blir-halvfinskt (hämtad I8/4 20I7).

39. "Schildts köper 40 procent av Alfabeta", Svensk Bokhandel 9/4 2003, http://www. svb.se/nyheter/schildts-koper-40-procent-av-alfabeta (hämtad I8/4 20I7).

40. Ekberg, Frisinne Eं kvalitet, s. 370.

4I. Ibid., s. 37I.

42. Lasse Winkler,"Schildts går ur Alfabeta", Svensk Bokhandel I2/2 2010, http://www. svb.se/nyheter/schildts-gar-ur-alfabeta (hämtad I8/4 20I7). 
nerade att följa Englunds exempel. ${ }^{43}$ I slutet av år 2015 köpte Natur $\&$ Kultur upp samtliga aktier i Atlantis. ${ }^{44}$

Vad innebar då dessa finlandssvenska förlagsuppköp och mellanspel på den sverigesvenska marknaden för spridningen av finlandssvensk litteratur i Sverige under perioden 2000-20I6? Om vi breddar perspektivet och tillåter oss att för en stund blicka utanför den här studiens ramar och beaktar den totala bokutgivningen, ser man att Atlantis torde vara det sverigesvenska förlag som under åren 2000-20I6 gav ut flest finlandssvenska titlar i delupplagor. Det handlar om cirka Iıo verk, de allra flesta med SLS (som alltså var majoritetsägare i Atlantis) som samarbetsförlag. Men det handlar främst om humaniora och vetenskaplig litteratur, samt i vissa fall källkritiska utgåvor av äldre skönlitteratur på svenska från Finland, vilket innebär att den stora majoriteten av titlarna inte motsvarar urvalskriterierna för verk i denna studie. Under Schildts turbulenta äktenskap med Alfabeta hann man ge ut ett stort antal nyutgåvor och nytryck av Tove Janssons klassiska Muminböcker i delupplagor på den sverigesvenska marknaden - och tillika många av de nyare Muminböckerna för mindre barn, skrivna av andra författare efter Tove Janssons död, men väldigt lite annat.

De finlandssvenska förlagens partiella förlagsuppköp i Sverige hade alltså ringa effekt på spridningen av ny finlandssvensk skönlitteratur i sverigesvenska delupplagor. Som Tabell I visar utkom endast två av Schildts nya skönlitterära titlar under perioden på Alfabeta, i båda fallen romaner av Robert Åsbacka, medan Söderströms lyckades få ut fem titlar i Sverige via Atlantis. I stället är det de två stora förlagsjättarna Albert Bonniers och Norstedts som tillsammans stod för över hälften av de nya skönlitterära delupplagorna åren 2000-20I6. Vid sidan av dessa gav Wahlström \&Widstrand ut åtta titlar i delupplaga, i samtliga fall diktsamlingar av Eva-Stina Byggmästar, och nämnda Atlantis sex titlar. I övrigt utkom enskilda titlar i delupplagor hos såväl större, väletablerade allmänutgivande förlag, som mindre samt ibland nischade aktörer.

43. Se t.ex. Annika Hällsten,"Peter Englund till attack mot Atlantis”, Hufoudstadsbladet I7/9 2013, http://gamla.hbl.fi/kultur/2013-09-I7/50107I/peter-englund-till-attackmot-atlantis (hämtad I8/4 20I7).

44. Kalle Laxgård,”Natur \& Kultur köper Atlantis", Svensk Bokhandel 21/12 20I5, http:// www.svb.se/nyheter/natur-kultur-koper-atlantis (hämtad I8/4 20I7). 
Tabell 1

Förlag i Sverige som utgett delupplagor av ny finlandssvensk skönlitteratur åren 2000-2016

\begin{tabular}{lc}
\hline Förlag & Antal titlar (sammanlagt 67) \\
\hline Albert Bonniers förlag & 21 \\
Norstedts & 13 \\
Wahlström \& Widstrand & 8 \\
Atlantis & 6 \\
Brutus Östlings bokförlag Symposion & 4 \\
H:ström Text \& kultur & 3 \\
Alfabeta & 2 \\
Edition Edda & 2 \\
Natur \& Kultur & 2 \\
Pequod Press & 2 \\
Heidruns & 2 \\
Ellerströms & 1 \\
Forum & 1 \\
\hline
\end{tabular}

\section{SATSNING PÅ ETABLERADE FÖRFATTARE}

Vilka finlandssvenska författare är det som fått sina nya skönlitterära verk utgivna i delupplagor i Sverige under 2000-talet? Som Tabell 2 visar är de 67 titlarna fördelade på 24 författarskap. Fyra namn sticker ut: Eva-Stina Byggmästar (9 titlar), Claes Andersson (8), Bo Carpelan (7) och Kjell Westö (6). Resterande tjugo författare på listan har fått en till tre nya titlar utgivna i delupplagor under perioden.

Det här innebär inte automatiskt att de fyra nämnda är de mest framgångsrika, mest lästa, mest uppskattade eller ens mest utgivna finlandssvenska författarna i Sverige under 200o-talet. Eftersom statistiken gäller skönlitterära förstautgåvor, omfattar den inte nyutgåvor, pocketböcker eller liknande. Studien ger alltså en bild av den nya finlandssvenska litteraturens spridning i Sverige, medan spridningen av klassiker eller bestseller i nya upplagor och utgåvor faller utanför dess ramar.

I stället för att visa vilka finlandssvenska författare som är mest spridda eller populära i Sverige, fokuseras här på vad som kännetecknar de författarskap som utgivits i delupplaga i Sverige under perioden. Man kan se att de sverigesvenska förlagen i mycket stor utsträckning har valt att satsa på äldre, väletablerade författarskap. Endast fyra av de aktuella författarna debuterade under 2000-talet, 
Tabell 2

Finlandssvenska författare med delupplagor av skönlitterära förstautgåvor åren 2000-2016

\begin{tabular}{lccl}
\hline Författare & $\begin{array}{c}\text { Delupplagor } \\
\text { 2000-2016 }\end{array}$ & $\begin{array}{c}\text { Skönlitterär } \\
\text { debut }\end{array}$ & $\begin{array}{l}\text { Första delupplaga } \\
\text { i Sverige }\end{array}$ \\
\hline Eva-Stina Byggmästar (f. 1967) & 9 & 1986 & 1994 W\&W \\
Claes Andersson (f. 1937) & 8 & 1962 & 1967 Bonnier \\
Bo Carpelan (1926-2011) & 7 & 1946 & 1946 Bonnier \\
Kjell Westö (f. 1961) & 6 & 1986 & 1986 Alba \\
Johan Bargum (f. 1943) & 3 & 1965 & 1967 Bonnier \\
Monika Fagerholm (f. 1961) & 3 & 1987 & 1994 Bonnier \\
Tua Forsström (f. 1947) & 3 & 1972 & 1979 Bonnier \\
Lars Sund (f. 1953) & 3 & 1974 & 1992 Tiden \\
Agneta Enckell (f. 1957) & 2 & 1982 & 1995 W\&W \\
Catharina Gripenberg (f. 1977) & 2 & 1999 & 2002 Norstedts \\
Johanna Holmström (f. 1981) & 2 & 2003 & 2013 Norstedts \\
Ulla-Lena Lundberg (f. 1947) & 2 & 1962 & 1982 Alba \\
Peter Mickwitz (f. 1964) & 2 & 1991 & 2004 Norstedts \\
Ulrika Nielsen (f. 1974) & 2 & 2001 & 2006 H:ström \\
Torsten Pettersson (f. 1955) & 2 & 1985 & 2005 Edition Edda \\
Philip Teir (f. 1980) & 2 & 2007 & 2013 Natur\&Kultur \\
Robert Åsbacka (f. 1961) & 2 & 1988 & 2006 Alfabeta \\
Ralf Andtbacka (f. 1963) & 1 & 1994 & 2008 Pequod Press \\
Jörn Donner (f. 1933) & 1 & 1951 & 1955 W\&W \\
Merete Mazzarella (f. 1945) & 1 & 1981 & 2009 Atlantis \\
Oscar Rossi (f. 1976) & 1 & 2002 & 2009 Pequod Press \\
Mikaela Strömberg (f. 1971) & 1 & 1999 & 2011 H:ström \\
Märta Tikkanen (f. 1935) & 1 & 1970 & 1974 Trevi \\
Curt West (f. 1959) & 1 & 1990 & 2003 Symposion \\
\hline
\end{tabular}

medan tjugo etablerade sig som skönlitterära författare under förra seklet, vissa så tidigt som på 1940- och I950-talen. Endast två åttiotalister finns på listan: Johanna Holmström, född ı98ı, och Philip Teir, född I980, är de två yngsta, och båda hade vid tiden för den första delupplagan hunnit bli en bit över trettio. Under perioden har inte en enda finlandssvensk författare fått sin skönlitterära debutbok utgiven i delupplaga i Sverige. Millenniets första, och i skrivande stund enda, finlandssvenska debutverk i delupplaga utkom i maj 20I7 (alltså utanför undersökningens tidsramar) då Martina Moliis-Mellbergs diktsamling $A$ gavs ut av Modernista (20I5 hos Schildts \& Söderströms).

Slutligen kan en viss könsmässig skillnad i utgivningen av delupplagor konstateras, även om den inte är stor. Som Diagram 4 och 5 illustrerar är fördelningen av antal kvinnliga respektive manliga författare med delupplagor relativt jämn (I3 män, II kvinnor), medan 
skillnaden är något större när man ser på andelen delupplagor: 39 titlar ( $5^{8}$ procent) är skrivna av män, 28 titlar ( 42 procent) av kvinnor. Jämförelser bakåt i tiden härvidlag hade naturligtvis varit önskvärt. Då det saknas tidigare statistik som tar fasta på de köns- eller åldersmässiga aspekterna låter det sig emellertid inte göras här.

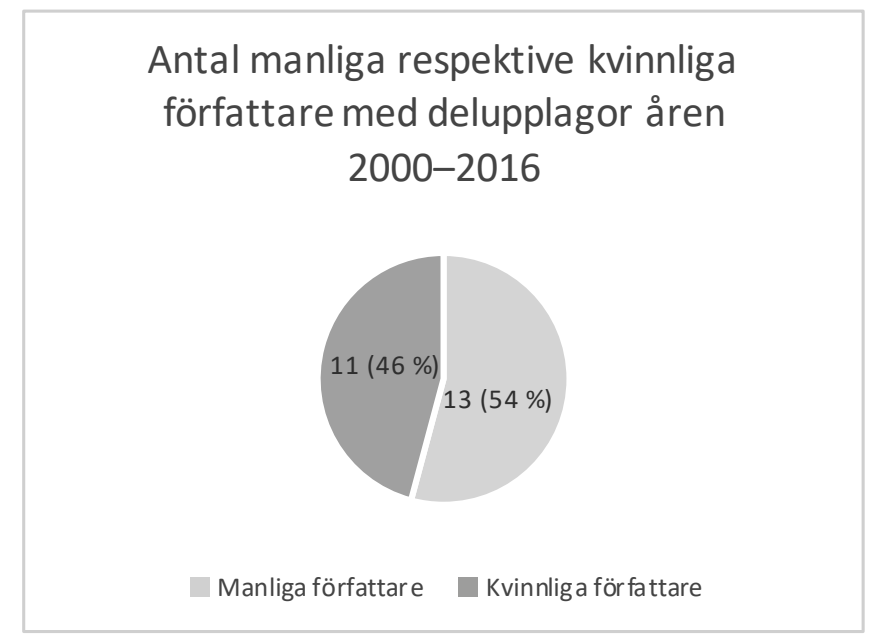

Diagram 4.

\section{Antal titlar i delupplaga åren 2000-2016, fördelning enligt författarens kön}

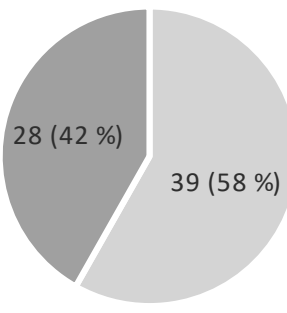


Genom det kvantitativa och systematiska tillvägagångssättet har jag i den här artikeln presenterat och diskuterat reella siffror och data gällande den skönlitterära utgivningen av finlandssvensk litteratur i delupplagor i Sverige under perioden 2000-20I6. Därtill har jag kunnat vederlägga några seglivade myter och uppfattningar om den finlandssvenska litteraturens position i Sverige i dag. I dagens läge utkommer nya skönlitterära delupplagor i Sverige i ungefär samma takt som under 1960- och 1970-talen, trots att flera bedömare uttryckt uppfattningen att den sverigesvenska tröskeln är avsevärt högre i dag. Det har också funnits en utbredd uppfattning om att särskilt lyriken blivit marginaliserad och styvmoderligt behandlad under senare tid. Så är inte fallet vad gäller utgivningen av ny finlandssvensk lyrik i Sverige, åtminstone inte i jämförelse med utgivningen av ny prosa: fler nya lyrikverk än prosaverk har alltså utkommit i sverigesvensk delupplaga åren 2000-20I6. Så är inte heller fallet om man jämför dagens situation med förhållandena under 1960- och 1970-talen, då majoriteten av delupplagorna som utkom i Sverige var prosa enligt Bengtssons och Engs studie.

Borde allt då vara till belåtenhet? Är en utgivningstakt på knappt fyra nya titlar i delupplaga per år i Sverige något man bör vara nöjd med? Så är det givetvis inte. Denna utgivning motsvarar en knapp femtedel av titlarna hos Schildts och Söderströms, samt nuvarande Schildts \& Söderströms, under den undersökta perioden - men en mycket mindre andel av utgivningen hos samtliga finlandssvenska förlag. Författare som skriver på svenska i Finland borde ha samma möjligheter att nå den svenskspråkiga majoriteten som de som skriver och utges i Sverige. Eller som Tuva Korsström formulerar det:

Frankrikes inkluderande inställning till den frankofona litteraturen är inte bara ett utslag av postkolonialism - det är också klok språkoch litteraturpolitik. Med en generösare inställning på svenskt håll kunde den finlandssvenska litteraturen integreras som en autonom men naturlig del av den svenskspråkiga litteraturen. ${ }^{45}$

45. Tuva Korsström, Från Lexå till Glitterscenen. Finlandssvenska tidsbilder, läsningar, författarporträtt 1960-20I3, Helsingfors: Schildts \& Söderströms 2013, s. I3. 
Återväxten bland de författare som når över nationsgränsen genom delupplagor är också bekymmersamt blygsam; förlagen i Sverige satsar oftast på väletablerade författarskap. Yngre förmågor och debutanter utkommer i mycket ringa grad i delupplagor.

Men varför är det så? Och varför satsar de sverigesvenska förlagen på vissa författarskap, och inte på andra, som också de blivit kritikerrosade och nått försäljningsframgångar på hemmamarknaden, och som i vissa fall också nått utanför dess gränser genom översättningar till både finska och andra språk? Den kvantitativa undersökningen ger inga svar på varför det är så; för att söka svaren krävs andra metoder och vidare studier, som Franco Moretti påpekat. Den kvantitativa metoden hjälper oss i stället att ställa rätt följdfrågor, sådana som inte från början har ett givet svar, framhåller Moretti vidare:"Och problem utan en lösning är exakt vad vi behöver på ett fält som vårt, där vi är vana att ställa enbart sådana frågor på vilka vi redan har ett svar." ${ }^{36}$

Också när det gäller den rena grundforskningen återstår mycket att göra på området. Undersökningar som tar fasta på här undantagna genrer, som barn- och ungdomslitteraturen, essäistiken eller facklitteraturen, skulle sannolikt generera en delvis annorlunda bild. En större studie som greppar en längre tidsperiod, eller flera mindre studier som inriktar sig på kortare perioder, skulle ge bättre förutsättningar för jämförelser över tid och ge värdefull kunskap om utvecklingslinjer.

Min studie ger ännu inte en helhetsbild av den finlandssvenska skönlitteraturens spridning i Sverige i dag. Fortfarande utkommer med jämna mellanrum exempelvis Johan Ludvig Runebergs, Edith Södergrans och Tove Janssons verk i nyutgåvor och nya upplagor. Samma sak gäller även för några av dagens fortsatt verksamma författare. Nyutgåvan av Märta Tikkanens moderna klassiker Årbundradets kärlekssaga (1978) utkom även som delupplaga hos Forum 2016 och boken fortsätter att hitta nya generationer av läsare också i Sverige. Tikkanen förekommer

46. "And problems without a solution are exactly what we need in a field like ours, where we are used to asking only those questions for which we already have an answer.", Franco Moretti, Graphs, Maps, Trees, London \& New York: Verso 2005, s. 26. Översättning till svenska: TR. Jfr även Andreas Hedberg, "Språk, genrer, författare. Sökningar i Kungl. bibliotekets bibliografi Suecana extranea", Johan Svedjedal (red.), Svensk litteratur som världslitteratur. En antologi, Uppsala: Avdelningen för litteratursociologi, Uppsala universitet 20I2, s. I25. 
även som gäst i sverigesvenska tv-program. Jörn Donner fortsätter att förtjusa och provocera med sin mediala persona, i tv likaväl som i nyskrivna självbiografiska och essäistiska böcker, och stora delar av hans enorma tidigare produktion har de senaste åren utkommit som e-böcker hos Wahlström \& Widstrand. Författarna med flest titlar enligt Tabell 2 är inte alltid de mest lästa, spridda, kritikerrosade eller berömda. Monika Fagerholm, med endast tre originaltitlar i denna undersökning, är kanske, jämte Tikkanen och Westö, den i dag mest inflytelserika finlandssvenska författaren i Sverige. Hon tilldelades Augustpriset 2005 (för Den amerikanska flickan), hon har rosats i pressen, hennes verk har utgivits i nya upplagor och pocketutgåvor.

I hur hög grad forskas det i Fagerholms - och i andra finlandssvenska - författarskap i Sverige? Att de finlandssvenska modernisterna med Edith Södergran i spetsen utövade stort inflytande på sina sverigesvenska kollegor är bekant. Vilka impulser kan dagens finlandssvenska författare generera? Allt detta är aspekter av hur finlandssvensk litteratur tas emot i Sverige, och borde även undersökas. För att inte tala om pressmottagandet: intervjuer, recensioner och andra artiklar, liksom mottagandet på nätet, i nättidningar, bloggar och annat. Och vilken position och plats intar den finlandssvenska litteraturen i litteraturhistoriska översiktsverk? Fältet förefaller outtömligt - och outforskat.

Här har jag kunnat visa att det inte var bättre förr - åtminstone inte under 1960- och 1970-talen om man ser till antalet delupplagor hos sverigesvenska förlag av ny finlandssvensk skönlitteratur. Samtidigt har jag också visat att anmärkningsvärt få yngre och debuterande finlandssvenska författare utkommit med delupplaga i Sverige efter millennieskiftet. Vad kan detta tänkas innebära för framtiden? En aspekt som talar för att detta förhållande kan komma att förändras - liksom det traditionella systemet med delupplagor - är att bokmarknaden och hela det litterära fältet i dag kanske mer än någonsin är statt i förändring och genomgår konstanta reformer. Framför allt är det yngre generationer som av hävd orienterar sig snabbast i ett föränderligt samhälle. Vad kan exempelvis den nya tekniken, med nya mediala plattformar och distributionsvillkor, komma att innebära för de traditionella litterära och kulturella nationsgränserna, för den nya författargenerationen och för den finlandssvenska litteraturens framtida avsättningsmöjligheter i Sverige? 


\section{BILAGOR}

Bibliografi över utgivningen av ny finlandssvensk skönlitteratur $i$ delupplagor hos sverigesvenska förlag åren 2000-20I6

2000

Kjell Westö: Vådan av att vara Skrake. Roman. Norstedts

2001

Eva-Stina Byggmästar: Den harhjärtade människan. Dikter. Lyrik.

Wahlström \& Widstrand

Bo Carpelan: Ögonblickets tusen årstider. Lyrik. Albert Bonniers

Ulla-Lena Lundberg: Marsipansoldaten. Roman. Albert Bonniers

2002

Claes Andersson: Dessa underbara stränder, förbi glidande. Dikter E prosadikter. Lyrik. Albert Bonniers

Catharina Gripenberg: Ödemjuka belles lettres från en till en. Lyrik.

Norstedts

2003

Johan Bargum: Avsked. Noveller. Atlantis

Eva-Stina Byggmästar: Näckrosön. Dikter. Lyrik. Wahlström \&

Widstrand

Bo Carpelan: Diktamina. Lyrik. Albert Bonniers

Tua Forsström: Jag studerade en gång vid en underbar fakultet. Lyrik.

Brutus Östlings bokförlag Symposion

Curt West: Taecken. Dikter. Lyrik. Brutus Östlings bokförlag

Symposion

Kjell Westö: Lang. Roman. Norstedts

2004

Claes Andersson: Det är kallt, det brinner. Fyrtiotvå dikter. Lyrik. Albert Bonniers

Peter Mickwitz: En rymdfarkost av glas. Dikter 199I-2004. Lyrik.

Norstedts

Lars Sund: Eriks bok. Roman. Norstedts 
Kjell Westö: Lugna favoriter. Berättelser i urval 1989-2004. Noveller. Norstedts

2005

Claes Andersson: Tidens framfart. Dikter. Lyrik. Albert Bonniers

Eva-Stina Byggmästar: Knoppar, blommor, blad och grenar. Dikter. Lyrik.

Wahlström \& Widstrand

Bo Carpelan. Berg. En roman. Roman. Albert Bonniers

Agneta Enckell: innanfor/utanfor $\left(\left(I^{+}\right) 3 \times I_{3}+\left(I^{+}\right)_{3} 3\right)$ (eller fyra olika

sätt att närma sig ett landskap). Lyrik. Brutus Östlings bokförlag

Symposion

Monika Fagerholm: Den amerikanska fickan. Roman. Albert Bonniers

Torsten Pettersson: Mörkret. Det börjar. Glansen. Den varar. En diktsvit. Lyrik. Edition Edda

2006

Eva-Stina Byggmästar: Älvdrottningen. Dikter. Lyrik. Wahlström \& Widstrand

Tua Forsström: Sånger. Lyrik. Brutus Östlings bokförlag Symposion Ulrika Nielsen: Mellan Linn Sand. Roman. H:ström Text \& kultur Kjell Westö: Där vi en gång gått. En roman om en stad och om vår vilja att bli högre än gräset. Roman. Norstedts

Robert Åsbacka: Kring torget i Skoghall. Roman. Alfabeta

2007

Bo Carpelan: Nya dikter. Lyrik. Albert Bonniers

Catharina Gripenberg: Ta min hand, det vore underligt. Lyrik. Norstedts

Peter Mickwitz: Där bara diset återstår av paradiset. Lyrik. Norstedts Torsten Pettersson: Jag ser en stjärna. Ett diktat porträtt av Carl von Linné. Lyrik. Edition Edda

2008

Claes Andersson: Lust. Dikter. Lyrik. Albert Bonniers

Eva-Stina Byggmästar: Men hur små poeter finns det egentligen. Lyrik.

Wahlström \& Widstrand

Bo Carpelan: Barndom. Roman. Albert Bonniers

Robert Åsbacka: Orgelbyggaren. Roman. Alfabeta 
Ralf Andtbacka: Österbottnisk gotik. Lyrik. Pequod Press

Ulrika Nielsen: En bok av kött och ord. Lyrik. H:ström Text \& kultur

2009

Monika Fagerholm: Glitterscenen och flickan hon går i dansen med röda gullband. Roman. Albert Bonniers

Oscar Rossi: Funny. Det vi vet om Jones är att Brown. Lyrik. Peqoud Press

Kjell Westö: Gå inte ensam ut i natten. Roman. Albert Bonniers

Lars Sund: En lycklig liten $\ddot{0}$. Roman. Norstedts

Merete Mazzarella: Ingen saknad, ingen sorg. En dag $i$ Zacharias Topelius liv. Roman. Atlantis

2010

Claes Andersson: Mörkrets klarhet. Lyrik. Heidruns

Eva-Stina Byggmästar: Vagga liten vagabond. Lyrik. Wahlström \& Widstrand

Bo Carpelan: Gramina: marginalia till Horatius, Vergilius och Dante. Lyrik. Albert Bonniers

Märta Tikkanen: Emma och Uno. Visst var det kärlek? Roman. Forum

2 OII

Claes Andersson: Ottos liv. En samtidsroman. Roman. Albert Bonniers Johan Bargum: Seglats i september. Roman. Atlantis

Bo Carpelan: Blad ur höstens arkiv. Tomas Skarfelts anteckningar. Roman. Albert Bonniers

Mikaela Strömberg: De vackra kusinerna. Roman. H:ström Text \& kultur

2012

Monika Fagerholm: Lola uppochner. Roman. Albert Bonniers Ulla-Lena Lundberg: Is. Roman. Albert Bonniers

2013

Claes Andersson: Hjärtats rum. Valda dikter 1962-20I2. Lyrik. Atlantis Eva-Stina Byggmästar: Locus Amoenus. Lyrik. Ellerströms Tua Forsström: En kväll rodde jag ut på sjön. Lyrik. Albert Bonniers 
Johanna Holmström: Asfaltsänglar. Roman. Norstedts Philip Teir: Akta dig for att färdas alltför fort. Noveller. Natur \& Kultur Philip Teir: Vinterkriget. En äktenskapsroman. Roman. Natur \& Kultur Kjell Westö: Hägring 38 . Roman. Albert Bonniers.

2014

Lars Sund: Tre systrar och en berättare. Roman. Norstedts Jörn Donner: Son och far. Historien om ett brott. Roman. Albert Bonniers Agneta Enckell: Inte ett ord (jag är naken). Lyrik. Atlantis Eva-Stina Byggmästar: Barrskogens barn. Lyrik. Wahlström \& Widstrand

2015

Claes Andersson: En morgon vid havet-inandning, utandning. Dikter. Lyrik. Heidruns

Johan Bargum: Noveller 1965-2015. Noveller. Atlantis Johanna Holmström: Hush baby. Roman. Norstedts Eva-Stina Byggmästar: I tvillingarnas tecken. Lyrik. Wahlström \& Widstrand

2016

Inga titlar 